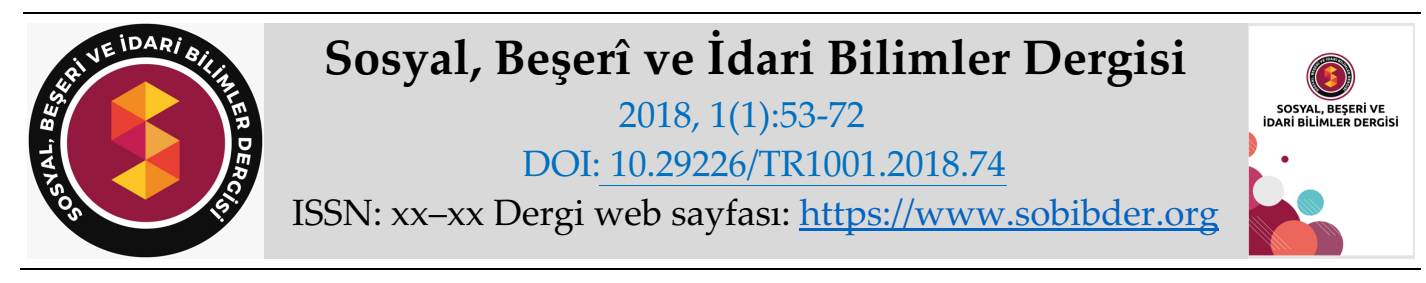

ARAȘTIRMA MAKALESI

\title{
Örgütsel Adalet ile Örgütsel Güven Algısının İşgören Performansı Üzerine Etkisinin Belirlenmesi
}

Rukiye ÖZDEMIR, Gazi Üniversitesi Sosyal Bilimler Enstitüsü, İnsan Kaynakları Yönetimi Anabilim Dalı, e-posta: rukiye.ozdemir1@gazi.edu.tr

ORCID: https://orcid.org/0000-0003-1392-4926

Öz

Araştırmada işgörenlerin örgütsel adalet algıları ile örgütsel güven düzeylerinin işgören performansı üzerindeki etkileri incelenmiştir. Araştırmanın evreni Türkiye'de kamu kuruluşlarında ve özel sektörde görev yapan işgörenlerden oluşmaktadır. Evrendeki araştırma grubuna ulaşmanın zorluğundan dolayı örneklem seçilmiştir. Örneklem grubundaki işgörenler Ankara ili ile sınırlı kalınmış olup örneklem sayısının belirlenmesinde basit tesadüfi örneklem formülünden yararlanılmıştır. Araştırmada problemi açıklamaya yönelik kamu kuruluşlarındaki ve özel sektördeki 415 işgörene uygulanan örgütsel adalet ve örgütsel güven arasındaki ilişki, anket sorularına verilen cevaplardan elde edilen verilerle analiz edilmiştir. Araştırmanın sonucunda işgörenlerin örgütsel adalet algıları ile örgütsel güven seviyeleri arasında anlamlı bir ilişkinin olduğu, her iki değişkenin de performans üzerinde etkisi olduğu, örgütsel adalet algıları ve örgütsel güven seviyeleri arasında bazı demografik değişkenler açısından anlamlı ilişkilerin olduğu tespit edilmiştir.

Anahtar Kelimeler: Örgütsel Adalet, Örgütsel Güven, Performans Değerlendirme.

Makale Gönderme Tarihi: 16.10 .2018

Makale Kabul Tarihi: 13.12. 2018

\section{Önerilen Atıf:}

Özdemir, R. (2018). Örgütsel Adalet ile Örgütsel Güven Algısının İşgören Performansı Üzerine Etkisinin Belirlenmesi, Sosyal, Beşeri ve İdari Bilimler Dergisi, 1(1):53-72.

C 2018 Sosyal, Beşerî ve İdari Bilimler Dergisi. 


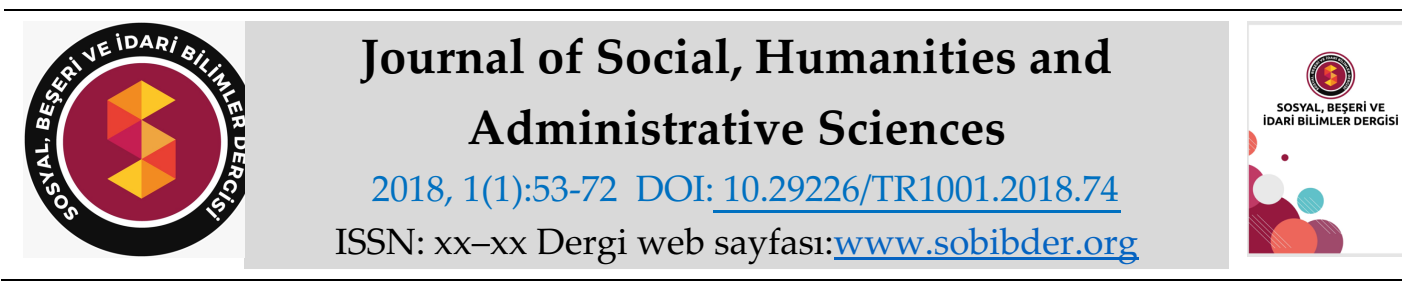

\title{
RESEARCH PAPER
}

\section{The Impact of Perceptions of Organizational Trust and Organizational Justice on Employee Performance}

Rukiye ÖZDEMIR, Gazi University, Institute of Social Sciences, Department of Human Resources Management, e-mail: rukiye.ozdemir1@gazi.edu.tr

ORCID: https://orcid.org/0000-0003-1392-4926

\begin{abstract}
In this research the relationship between employees' perception of organizational justice and their organizational trust levels' impact on employee performance was investigated the scope of research is comprised of employees serving in public and private sector in Turkey A sample was taken due to the difficulty in reaching study group. The employees in study group were enrolled from Ankara. A simple coincidental sampling formula was utilized while determining the number of samples. In this research the relationship between perception of organizational justice and organizational trust applied to 415 employees serving in public and private sector was analyzed through using data obtained from answers given to survey questions. As a result of research, it was established that there was a significant relationship between employees' perception of organizational justice and organizational trust levels; and their impact on employee's performance; however, there were significant relationships between perception of organizational justice and their organizational trust levels in terms of certain demographic variables.
\end{abstract}

Keywords: Organizational Justice, Organizational Trust, Performance Evaluation.

Received: 16.10 .2018

Accepted: 13.12 .2018

\section{Suggested Citation:}

Özdemir, R. (2018). The Impact of Perceptions of Organizational Trust and Organizational Justice on Employee Performance, Journal of Social, Humanities and Administrative Sciences, 1(1):53-72.

(C) 2018 Sosyal, Beşerî ve İdari Bilimler Dergisi. 


\section{Gíriş}

Örgütler, insanların istek ve ihtiyaçlarını karşılamak amacıyla üretim faktörlerini optimal şekilde bir araya getirerek mal veya hizmet üretip satışa sunan, temel olarak kar, sosyal fayda ve devamlılık amacı güden ekonomik birimlerdir (Üner, 2008:21). Bu birimlerin en önemli bileşenlerinden biri örgüt çalışanlarıdır. Diğer bir ifade ile örgütün sürekliliği açısından çalışanların önemi büyüktür.

Üner (2008:71)'in diğer tanımına göre; örgütler, insanların oluşturduğu ve belirli amaçlar doğrultusunda çıktılar sağlamaya yönelik faaliyetleri olan topluluklardır. Örgütün bu tanımında belirli amaçlardan bahsedilmektedir. Buradaki amaç müşterektir, kişilerin ortak çıkarlar doğrultusunda bir araya gelmesidir. Dolayısıyla örgüt çalışanları da kendisini örgütün bir parçası olarak hissetmekte, o atmosfer örgütte oluşturulmaktadır.

Örgütte işgörenlerin davranışlarını etkileyen birtakım kavramlar mevcuttur. Bunlardan bir tanesi güven kavramıdır. Güven, bireyin karşısındaki kişiye itibar etmesi, değer vermesi için gündelik hayatta bile önemli bir kavramdır. Paralel olarak örgüte güven de örgütün tercih edilme olasılığını önemli ölçüde artırır. Örgütsel güven, işletmenin işgören-işveren bütünlüğünü sağlar. Güven ikliminin örgütün tüm bölümlerinde hissedilebilmesi için örgütteki tüm bireylerin katkısıyla uzun bir zaman gerekliliği araştırmacılar tarafından ileri sürülmektedir.

İşgörenin örgüt içindeki tutum ve davranışlarını etkileyen bir diğer kavram adalettir. Adalet, hakkın yerine getirilmesi doğruyla yanlışın ayırt edilmesi ve ona göre davranılmasıdır. Adaletin hissedildiği örgütte işgören kendisini huzurlu hisseder, yaptığı işi severek yapar. Örgütsel adalet ise örgüt işgörenlerinin yaptıkları işleriyle alakalı kendilerine adil davranılıp davranılmadığına inanmaları ve bu inançla işleriyle alakalı daha olumlu davranışlarda bulunmaları ve sonucunda ortaya koydukları çıktıyla alakalı değişiklikleri ifade eden bir kavramdır (Moorman, 1991:845). İsgörenlerde adalet algısının düşük olduğu, ödül-ceza dağıtımında adaletsiz davranıldığ hissinde; işgörenin moralinin düştüğünü, örgütten ayrılma olasılığının arttığını, ahlaki davranışını etkilediğini ve hatta örgüt aleyhinde birtakım faaliyetlerde bulunabildikleri çalışmalar sonucunda ortaya çıkmaktadır (Cihangiroğlu ve Yılmaz, 2010: 209). Örgütsel adalet ve örgütsel güven kavramlarının ikisi de örgütte sağlandığı takdirde ne gibi sonuçlara neden olacağ 1 ise performans ile ölçülebilir. Bu bağlamda performans değerlendirme, işgörenin işe yöneltilmesini, özendirilmesini ve örgüte duyduğu güvenin arttırılmasını sağlayan bir araç olarak görülebilir (Cohen, 1992:192). İşgören, diğer arkadaşlarıyla beraber aynı ortamlarda çalışıyor ve etkileşim halindeyse kendisini onlarla kıyaslayacaktır. Bu kıyaslama bazı kıstaslar içermektedir. Bunlardan en önemlisi ise haliyle işgörenin emeği karşılığında elde ettiği ücrettir. Ücret örneğinden yola çıkılacak olursa; işgören, kendisiyle aynı işi yaptığına inandığı diğer arkadaşlarıyla farklı miktarda maaş aldığını öğrendiğinde bunu sorgulayacaktır. İster istemez zamanla bu algısı, duygu ve düşüncesine yansıyacaktır. Sonuç olarak performansını etkileyecektir. Bu duruma mahal vermemek için örgütteki bu algıyı düzenlemek için birtakım adımlar atılma zorunluluğu ortaya çıkmaktadır. İşgörenin, işverene karşı güven hissi ve diğer iş arkadaşları arasındaki adalet algısı, performansını etkileyecek önemli hususlardandır.

$\mathrm{Bu}$ çalışmada, bahsedilen tüm bu kavramlar ile işgörenlerin performansı ve yönetimin performans değerlendirmesi hususlarına olan etkilerini ortaya çıkarmak hedeflenmektedir. Ayrıca, örgütsel adalet ve örgütsel güven algısının, örgüt için önemi ve işgören performansı üzerine etkisi araştırılacaktır. 
Araştırmanın amacına dayanarak aşağıdaki hipotezler test edilecektir:

$\mathrm{H}_{1}$ : İşgörenlerin örgütsel güven algıları ve örgütsel adalet algıları arasında ilişki vardır.

$\mathrm{H}_{2}$ : İşgörenlerin örgütsel güven algıları ile performansları arasında ilişki vardır.

$\mathrm{H}_{3}$ : İşgörenlerin örgütsel adalet algıları ile performansları arasında ilişki vardır.

a) Cinsiyet değişkeni;

$\mathrm{H}_{4 a}$ : Cinsiyet değişkeni açısından; işgörenlerin örgütsel güven algılarında farklılaşma vardır.

$\mathrm{H}_{4 b}$ : Cinsiyet değişkeni açısından; işgörenlerin örgütsel adalet algılarında farklılaşma vardır.

$\mathrm{H}_{4 c}$ : Cinsiyet değişkeni açısından; işgörenlerin performans düzeylerinde farklılaşma vardır.

b) Çalışma süresi değişkeni;

H5a:: Çalışma süresi açısından; işgörenlerin örgütsel güven algılarında farklılık vardır.

H5b: Çalışma süresi açısından; işgörenlerin örgütsel adalet algılarında farlılık vardır.

H5: Çalışma süresi açısından; işgörenlerin performans düzeyleri arasında farlılık vardır.

c)Kurumun özel veya kamu olması değişkeni;

$\mathrm{H}_{6 a}:$ Kamu ve özel kurumlar açısından; işgörenlerin örgütsel güven algılarında farlılık vardır.

H6b: Kamu ve özel kurumlar açısından; işgörenlerin örgütsel adalet algılarında farlılık vardır.

$\mathrm{H}_{6 c:}$ Kamu ve kurumlar açısından; işgörenlerin performans düzeylerinde farlılık vardır.

d) Yaş değişkeni;

H7a: Yaş değişkeni açısından; işgörenlerin örgütsel güven algılarında farklılık vardır.

Hъb: Yaş değişkeni açısından; işgörenlerin örgütsel adalet algılarında farlılık vardır.

$\mathrm{H}_{7 \mathrm{c}:}$ Yaş değişkeni açısından; işgörenlerin performans düzeylerinde farlılık vardır.

e) Eğitim durumu değişkeni;

H8a: Eğitim durumu değişkeni açısından; işgörenlerin performans düzeylerinde farlılık vardır.

$\mathrm{H}_{8 b}$ : Eğitim durumu değişkeni açısından; işgörenlerin örgütsel adalet algılarında farlılık vardır.

H8c: Eğitim durumu değişkeni açısından; işgörenlerin örgütsel güven algılarında farklılık vardır.

f) Yöneticilik durumu değişkeni;

H9a: Yöneticilik durumu açısından; işgörenlerin örgütsel güven algılarında farlılık vardır.

H9b: Yöneticilik durumu açısından; işgörenlerin örgütsel adalet algılarında farklılık vardır.

H9c: Yöneticilik durumu açısından; işgörenlerin performans düzeylerinde farlılık vardır.

\section{YÖNTEM}

\section{Evren ve Örneklem}

Araştırmanın evreni Türkiye'de kamu ve özel kurumlarında görev yapan işgörenlerden oluşmaktadır. Evrendeki araştırma grubuna ulaşmanın zorluğundan dolayı örneklem seçilmiştir. Örneklem grubu başkent Ankara'da kamu ve özel sektörlerde görev yapan işgörenlerden oluşmaktadır. Örneklem sayısının belirlenmesinde basit tesadüfi örneklem formülünden yararlanılmıştır. Aşağıda basit tesadüfi örneklem formülü verilmiştir;

$$
\mathrm{n}=\frac{\mathrm{NPq}}{\frac{(\mathrm{N}-1) \mathrm{B}^{2}+\mathrm{Pq}}{\mathrm{Z}^{2}}}
$$

$\mathrm{n}=$ Örneklem sayısı

$\mathrm{N}=$ Araştırmaya konu olan topluluk

$\mathrm{P}=$ Topluluk oranı

$\mathrm{Q}=1-\mathrm{P}$

$\mathrm{B}=$ Katlanılabilir hata oranı

$\mathrm{Z}=$ İstenilen güven aralığını ifade etmektedir. 


\section{$1.783 .357 * 1,96 * 0,5 * 0,5$ \\ $387=\overline{1.783 .357 * 0,5^{2}+1,96^{2} * 0,5 * 0,5}$}

Araştırma evrenini oluşturan Ankara'da çalışan sayısı 2017 verilerine göre 1.783.357' dir. (Ankara Kalkınma Ajansı, 2017: 163). Formül evrene uyarlandığında örneklem büyüklüğü 387 olarak belirlenmiştir. Evrenden seçilen örneklem grubundan 415 işgörene ulaşılmıştır.

\section{Kapsam ve Sinurlılıklar}

Araştırmada Ankara ilindeki çeşitli kamu kurumu kuruluşlarında ve özel sektörlerde çalışan işgörenlerinin örgütsel adalet ve örgütsel güven algısının işgören performansı üzerine etkileri incelenecektir. Bu işgörenler çalışmamızın evrenini oluşturacaktır. Seçilecek olan kamu ve özel sektör örgütleri işgörenlerinin tüm evreni temsil ettiği varsayılacaktır. Araştırma, seçilmiş olan bu örgütlerle sinırlı kalacaktır.

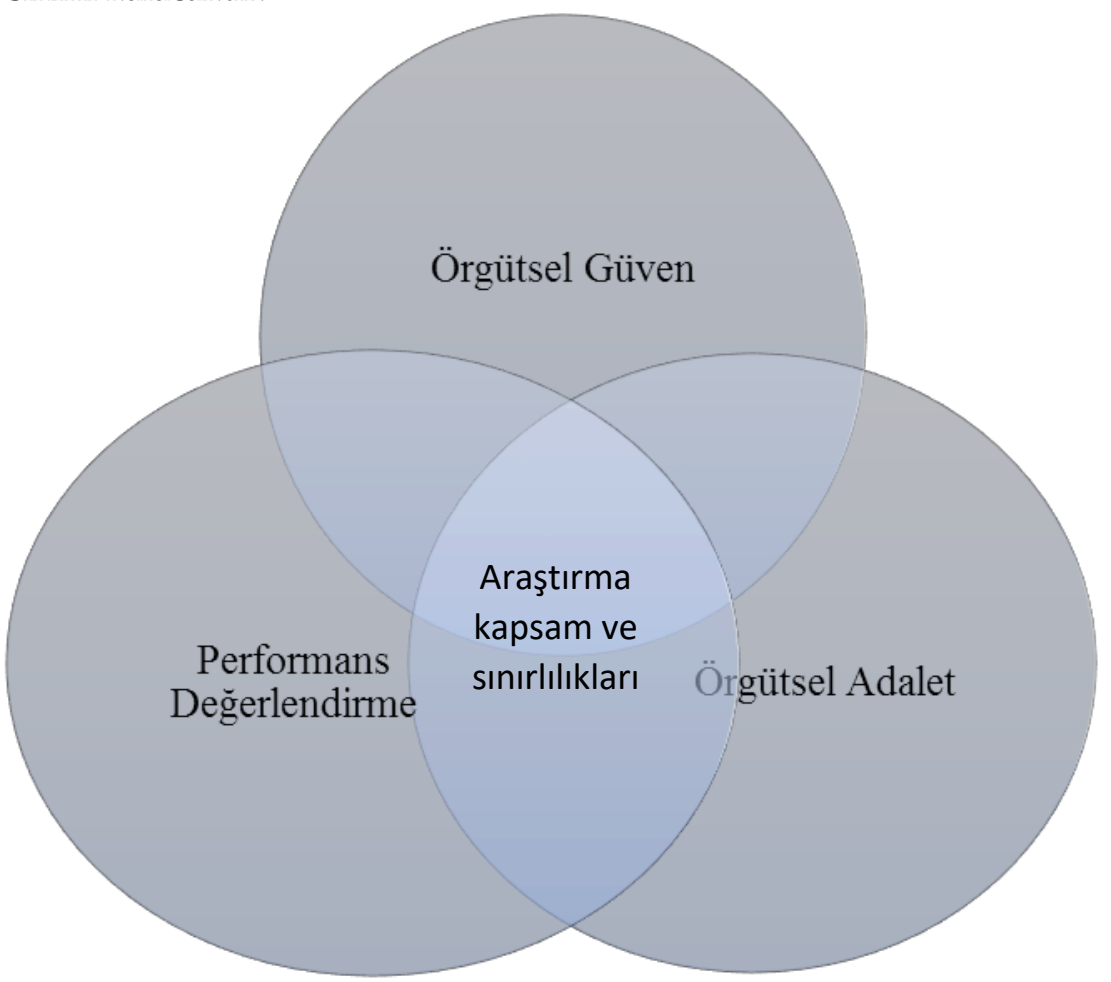

Şekil 1. Araştırmanın Kapsam ve Sınırlılıkları

Araştırmada üç ana kavram kullanılmıştır; bunlardan birincisi, örgütsel güven, ikincisi, örgütsel adalet, üçüncüsü ise performans değerlendirmedir. Araştırma amacımız uyarınca örgütsel güven ve örgütsel adalet kavramlarının işgören performansı üzerinde herhangi bir etkisi olup olmadığı ile ilgili verilere ulaşılıp analizler yapılacaktır. İşören performansını etkileyen unsurlar arasından yalnızca güven ve adalet kavramları ele alınacaktır. Başka bir ifade ile performansı etkileyen örgütte pek çok faktör bulunmaktadır. Bu araştırmada farklılaşmaya sadece bu faktörlerden örgütsel güven ve örgütsel adalet kapsamında bakılacaktır.

Yapılacak anket çalışmasında toplanan nicel verilerin geçerlilik ve güvenirliği, veri toplamada kullanılan anket tekniğinin nitelikleri ile sınırlı olacaktır. Ayrıca sosyal bilimler araştırmalarına özgü genel sınırlılıklar, yapılacak bu araştırma için de geçerli olacaktır. 


\section{Verilerin Analizi}

Çalışmada bu bölümünde verilen toplanması, alt problemler ve alt problemlerin test edilmesine ilişkin istatistiksel testler yer almaktadır.

Bu araştırmanın değişkenleri örgütsel adalet, örgütsel güven ve performans düzeyidir. Her üç değişkeni ölçmek için uygulanacak ölçekler belirlenen örneklemdeki Ankara'da kamu ve özel kurumlarda görev yapan işgörenlere uygulanmıştır. Uygulama alanındaki bireylerin anketlere verdikleri cevaplar SPSS (Statistical Program for Social Sciences) paket programı ile bilgisayar ortamına aktarılmıştır.

Örgütsel Adalet ve Güven Algısı Ölçeği ve Performans Değerlendirme Ölçeği'nden oluşan 550 anket daha önceden tesadüfî olarak belirlenen örneklem grubu içindeki bölgelere elden, kargo ile ve e-posta ile ulaştırılmıştır. Bu anketlerden 449 tanesi geri dönmüştür ve anketler değerlendirmeye tabi tutulmuştur.

Araştırmada elde edilen veriler, araştırmanın amacı doğrultusunda çeşitli istatistikî analizler (frekans, $\mathrm{t}$ testi, One-Way Anova, Pearson Korelasyon) kullanılarak ve konuya ilişkin uzman desteği alınarak yorumlanmıştır.

\section{BULGULAR VE YORUM}

Bu bölümde araştırmaya konu olan araştırma grubunun genel yapısına yönelik tanıtıcı frekans ve yüzde dağılımlarına yer verilmiştir.

Tablo 1. Araştırmaya Katılan İşgörenlerin Yaş Dağılımı

\begin{tabular}{|l|l|l|}
\hline Yaş & $\mathbf{N}$ & $\mathbf{\%}$ \\
\hline $20-25$ & 46 & 11,1 \\
\hline $26-30$ & 68 & 16,4 \\
\hline $31-35$ & 87 & 21,0 \\
\hline $36-40$ & 68 & 16,4 \\
\hline 41 ve üzeri & 146 & 35,2 \\
\hline Toplam & $\mathbf{4 1 5}$ & $\mathbf{1 0 0 , 0}$ \\
\hline
\end{tabular}

Araştırmaya katılan örneklem grubunun \%35,2'si 41 ve üzeri yaş grubunda, \%21'i 31-35 yaşları arasında, \%16,4'ü 36-40 yaşları arasında, \%16,4'ü 26-30 yaşları arasında, \%11,1'i ise 26-30 yaşları arasındadır. Yüzde ve frekans tablosundaki dağılımlara göre işgörenlerin büyük çoğunluğunun 41 ve üzeri yaş grubudur.

Tablo 2. Araştırmaya Katılan İşgörenlerin Cinsiyet Dağılımı

\begin{tabular}{|l|l|l|}
\hline Cinsiyet & N & \% \\
\hline Kadın & 132 & 31,8 \\
\hline Erkek & 283 & 68,2 \\
\hline Toplam & $\mathbf{4 1 5}$ & $\mathbf{1 0 0 , 0}$ \\
\hline
\end{tabular}


Araştırmaya katılan işgörenlerin \%31,8' i kadın ve \%68,2'si da erkektir. Örneklem grubunun büyük çoğunluğu erkeklerden oluşmaktadır.

Tablo 3. Araştırmaya Katılan İşgörenlerin Çalışma Yılına Göre Dağılımı

\begin{tabular}{|l|l|l|}
\hline Çalışma Y1li & $\mathbf{N}$ & $\mathbf{\%}$ \\
\hline $0-1$ & 33 & 8,0 \\
\hline $2-5$ & 94 & 22,7 \\
\hline $6-10$ & 77 & 18,6 \\
\hline $11-15$ & 56 & 13,5 \\
\hline 16 ve üzeri & 155 & 37,3 \\
\hline Toplam & $\mathbf{4 1 5}$ & $\mathbf{1 0 0 , 0}$ \\
\hline
\end{tabular}

Araştırmaya katılanların çalışma yılı yüzde ve frekans dağılımına baktığımızda; işgörenlerin \%37,3'ü 16 yıl ve üzeri, \%22,7'si 2 ve 5 yıl arası, \%18,6'sı 6 ve 10 yıl arasında, \%13,5'i 11 ve 15 yıl arası \%8'i de 0 ve 1 yıl arası çalışma süreleri vardır.

Tablo 4. Araştırmaya Katılan İşgörenlerin Eğitim Durumuna Göre Dağılımı

\begin{tabular}{|l|l|l|}
\hline Eğitim Durumu & $\mathbf{N}$ & $\mathbf{\%}$ \\
\hline İlköğretim & 27 & 6,5 \\
\hline Lise & 98 & 23,6 \\
\hline Ön lisans & 57 & 13,7 \\
\hline Lisans & 178 & 42,9 \\
\hline Lisansüstü & 55 & 13,3 \\
\hline Toplam & $\mathbf{4 1 5}$ & $\mathbf{1 0 0 , 0}$ \\
\hline
\end{tabular}

Araştırmaya katılımcıların eğitim durumu istatistiğine bakıldığında en büyük payı \%42,9 ile lisans mezunları almaktadır. İkinci sırada ise \%23,6 ile lise mezunları yer almaktadır. Diğer istatistikler ile şöyledir: \%13,7'si ön lisans, \%13,3 ile lisansüstü, \%6,5'i ise ilköğretim mezunudur.

Tablo 5. Araştırmaya Katılan İşgörenlerin Kurum Türüne Göre Dağılımı

\begin{tabular}{|l|l|l|}
\hline Kurum Türü & $\mathbf{N}$ & $\mathbf{\%}$ \\
\hline Kamu & 245 & 59,0 \\
\hline Özel & 170 & 41,0 \\
\hline Toplam & $\mathbf{4 1 5}$ & $\mathbf{1 0 0 , 0}$ \\
\hline
\end{tabular}

Araştırmaya katılan örneklem grubundaki işgörenlerin \%59'u kamu kurumunda görevliyken, \%41'i özel kurumlarda görev yapmaktadır. Örneklem grubundaki işgörenlerin çoğunluğu kamu kurumunda görevlidir. Ancak önemli bir farklılık da bulunmamaktadır.

Tablo 6. Araştırmaya Katılan İşgörenlerin Yöneticilik Durumuna Göre Dağılımı

\begin{tabular}{|l|l|l|}
\hline Yöneticilik Durumu & N & \% \\
\hline Evet & 94 & 22,7 \\
\hline Hayır & 321 & 77,3 \\
\hline Toplam & 415 & 100,0 \\
\hline
\end{tabular}


Katılımcıların \%22,7'si yöneticilik pozisyonunda iken \%77,3'ünde yöneticilik pozisyonu bulunmamaktadır.

Tablo 7. İşgörenlerin Örgütsel Adalet ve Örgütsel Güven Değerlendirmelerinin Ortalamaları

\begin{tabular}{|l|l|l|l|}
\hline Ölçek & Güven Algısı & Adalet Algısı & $\begin{array}{l}\text { Performans } \\
\text { Değerlendirmesi }\end{array}$ \\
\hline $\bar{X}$ & 3,5805 & 3,4411 & 4,2000 \\
\hline SS &, 84715 &, 90950 &, 67755 \\
\hline En Düşük & 1,07 & 1,00 & 1,25 \\
\hline En Büyük & 5,00 & 5,00 & 5,00 \\
\hline N & 415 & 415 & 415 \\
\hline
\end{tabular}

Araştırmaya katılan işgörenlerin örgütsel güven ve adalet algılarının ve performans düzeylerinin tespit edilmesi amacıyla çalışanlara 5'li Likert tipinde derecelendirilen sırayla 27, 20 ve 8 maddeden oluşan bir ölçek uygulanmıştır. Çalışanların ölçek maddelerine vermiş oldukları cevaplar doğrultusunda hesaplanan betimsel istatistikler yukarıdaki Tabloda gösterilmiştir.

Tablo incelendiğinde, araştırmaya katılan örneklem grubunun örgütsel adalet, örgütsel güven ve performans değerlendirme ortalamaları incelendiğinde işgörenlerin performans değerlendirmeleri ortalamalarının daha yüksek olduğu tespit edilmiştir. Akabinde örgütsel güven algılarının ortalaması örgütsel adalet algısına göre daha yüksek olduğu görülmektedir. Ancak aralarında küçük bir fark bulunmaktadır.

Tablo 8. İşgörenlerin Örgütsel Adalet ve Güven Algıları Düzeyleri Arasındaki İlişki

\begin{tabular}{|l|l|l|l|}
\hline \multicolumn{2}{|l|}{} & Örgütsel Güven & Örgütsel Adalet \\
\hline \multirow{5}{*}{ Örgütsel Güven } & $\mathrm{R}$ & 1 &, 875 \\
\cline { 2 - 4 } & $\mathrm{P}$ & &, 000 \\
\cline { 2 - 4 } & $\mathrm{N}$ & 415 & 415 \\
\hline \multirow{3}{*}{ Örgütsel Adalet } & $\mathrm{R}$ &, 875 & 1 \\
\cline { 2 - 4 } & $\mathrm{P}$ &, 000 & 415 \\
\cline { 2 - 3 } & $\mathrm{N}$ & 415 & \\
\hline
\end{tabular}

$\mathrm{H}_{1}$ : İşgörenlerin örgütsel güven algıları ve örgütsel adalet algıları arasında ilişki vardır. Araştırmaya katılan örneklem grubunun örgütsel güven ve örgütsel adalet düzeyleri arasındaki ilişkiye bakılmış olup 0,01 önem düzeyinde anlamlı bir ilişki tespit edilmiştir ve ilişkinin şiddeti $r=, 875$ olduğu görülmektedir. Diğer bir ifade ile örgütsel adalet ve örgütsel güven arasında dikkate değer bir ilişki bulunmuştur. Yapılan analizde bulunan korelasyon katsayısının anlamlılığın oldukça yüksek olduğu $(\mathrm{p}=0,000)$ tespit edilerek $\mathrm{H}_{1}$ hipotezi yeterli kanıtla desteklenmiştir.

$\mathrm{H}_{2}$ : İşgörenlerin örgütsel güven algıları ile performansları arasında ilişki vardır. Araştırmaya katılan örneklem grubunun örgütsel adalet algıları ile performansları düzeyleri arasındaki ilişkiyi bakılmış olup $p<0,01$ önem düzeyinde anlamlı bir ilişki tespit edilmiş ve ilişkinin şiddeti $\mathrm{r}=, 375$ olduğu görülmektedir. İşgörenlerin örgütsel adalet algısı ve performansları arasında istatistiksel olarak dikkate değer bir ilişki bulunmuştur. Yapılan analizde bulunan korelasyon 
katsayısının anlamlılığın oldukça yüksek olduğu $(\mathrm{p}=0,000)$ tespit edilerek $\mathrm{H}_{2}$ hipotezi yeterli kanıtla desteklenmiştir.

Tablo 9. İşgörenlerin Örgütsel Güven ve Performans Düzeyleri Arasındaki İlişki

\begin{tabular}{|l|l|l|l|}
\hline \multicolumn{2}{|l|}{} & Örgütsel Güven & Performans D. \\
\hline \multirow{3}{*}{ Örgütsel Güven } & $\mathrm{R}$ & 1 &, 375 \\
\cline { 2 - 4 } & $\mathrm{P}$ & &, 000 \\
\cline { 2 - 4 } & $\mathrm{N}$ & 415 & 415 \\
\hline \multirow{2}{*}{$\begin{array}{l}\text { Performans } \\
\text { Değerlendirme }\end{array}$} & $\mathrm{R}$ &, 375 & 1 \\
\cline { 2 - 4 } & $\mathrm{P}$ &, 000 & 415 \\
\cline { 2 - 3 } & $\mathrm{N}$ & 415 & \\
\hline & $* *$ Korelasyon 0.01 seviyesinde anlamlıdır. \\
\hline
\end{tabular}

Tablo 10. Örgütsel Güven Algısının Bireysel Performans Üzerindeki Etkileri

\begin{tabular}{|l|l|l|l|l|l|l|}
\hline Model & $\mathbf{R}$ & $\mathbf{R}^{2}$ & Düzeltilmiş $\mathbf{R}^{\mathbf{2}}$ & Std. Hata & $\mathbf{F}$ & $\mathbf{P}$ \\
\hline 1 &, 375 &, 141 &, 138 &, 78632 & 67,530 &, 000 \\
\hline
\end{tabular}

*.05 düzeyinde anlamlı (çift taraflı) **.01 düzeyinde anlamlı (çift taraflı)

Model istatistiksel olarak anlamlı bulunmuştur ( $\mathrm{p}<0.005)$. Ayrıca $\mathrm{R}^{2}=0.141$ 'dir. Bir başka ifade ile, işgörenin örgütsel güven algısının performans üzerine $\% 14,1$ oranında etkisi vardır. Oran düşük değildir. İşgörenin işyerinde performansını etkileyen birçok etki vardır, bunlardan \% 14 'ü örgütsel güven algısıyla alakalı olduğu saptanmıştır.

Tablo 11. İşgörenlerin Örgütsel Adalet ve Performans Düzeyleri Arasındaki İlişki

\begin{tabular}{|l|l|l|l|}
\hline \multicolumn{2}{|l|}{} & Örgütsel Adalet & Performans D. \\
\hline \multirow{3}{*}{ Örgütsel Adalet } & $\mathrm{R}$ & 1 &, 348 \\
\cline { 2 - 4 } & $\mathrm{P}$ & &, 000 \\
\cline { 2 - 4 } & $\mathrm{N}$ & 415 & 415 \\
\hline \multirow{2}{*}{$\begin{array}{l}\text { Performans } \\
\text { Değerlendirme }\end{array}$} & $\mathrm{R}$ &, 348 & 1 \\
\cline { 2 - 4 } & $\mathrm{P}$ &, 000 & 415 \\
\cline { 2 - 3 } & $\mathrm{N}$ & 415 & \\
\hline \multirow{2}{*}{${ }^{* * \text { Korelasyon 0.01 seviyesinde anlamlıdır. }}$} \\
\hline
\end{tabular}

$\mathrm{H}_{3}$ : İşgörenlerin örgütsel adalet algıları ile performansları arasında ilişki vardır. Araştırmaya katılan örneklem grubunun örgütsel adalet algıları ile performans düzeyleri arasındaki ilişkiyi bakılmış olup $\mathrm{p}<0,01$ önem düzeyinde anlamlı bir ilişki tespit edilmiş ve ilişkinin şiddeti $r=, 348$ olduğu görülmektedir. Örgütsel adalet ve performans arasında istatistiksel olarak dikkate değer kuvvetli bir ilişki bulunmuştur. Yapılan analizde bulunan korelasyon katsayısının anlamlılığın oldukça yüksek olduğu $(\mathrm{p}=0,000)$ tespit edilerek $\mathrm{H}_{3}$ hipotezi yeterli kanıtla desteklenmiştir.

Tablo 12. Örgütsel Adalet Algısının Bireysel Performans Üzerindeki Etkileri

\begin{tabular}{|l|l|l|l|l|l|l|}
\hline Model & $\mathbf{R}$ & $\mathbf{R}^{2}$ & Düzeltilmiş $\mathbf{R}^{2}$ & Std. Hata & $\mathbf{F}$ & $\mathbf{P}$ \\
\hline 1 &, 348 &, 121 &, 119 &, 85382 & 56,756 &, 000 \\
\hline
\end{tabular}

*.05 düzeyinde anlamlı (çift taraflı) ${ }^{* *} .01$ düzeyinde anlamlı (çift taraflı) 
Örgütsel adalet algısının bireysel performans üzerindeki etkisinin incelendiği regresyon modeli değerlendirildiğinde, örgütsel güvenin bireysel performans üzerinde $\% 1$ anlamlılık düzeyinde ve olumlu yönde güçlü bir etkisinin olduğu görülmektedir. Tablodan çıkacak sonuç ise $\mathrm{R}^{2}=0,121^{\prime}$ dir ve örgütsel adalet algısının işgörenin işyerindeki performansı üzerine etkisi $\% 12,1$ oranındadır. Performansı etkileyen birçok etmen olduğu bilindiğine göre işgörenin adalet algısının payı düşük değildir. Ayrıca model istatistiksel olarak anlamlı bulunmuştur $(p<0.005)$.

Tablo 13. İşgörenlerin Örgütsel Adalet ve Güven Algıları ve Performans Düzeylerinin Cinsiyet Değişkeni Açısından Farklılaşması

\begin{tabular}{|l|l|l|l|l|l|l|}
\hline & Cinsiyet & $\mathbf{N}$ & $\bar{X}$ & s.s. & $\mathbf{T}$ & $\mathbf{p}$ \\
\hline \multirow{2}{*}{ Örgütsel Güven } & Kadın & 132 & 3,6063 &, 82195 &, 425 &, 671 \\
\cline { 2 - 5 } & Erkek & 283 & 3,5684 &, 85981 & & \\
\hline \multirow{2}{*}{ Örgütsel Adalet } & Kadın & 132 & 3,4670 &, 88815 & \multirow{2}{*}{, 397} & \multirow{2}{*}{, 692} \\
\cline { 2 - 5 } & Erkek & 283 & 3,4290 &, 92059 & & \\
\hline Performans & Kadın & 132 & 4,2661 &, 64249 & 1,359 &, 175 \\
\cline { 2 - 4 } & Erkek & 283 & 4,1692 &, 69225 & & \\
\hline
\end{tabular}

$\mathrm{H}_{4-a}$ : Cinsiyet değişkeni açısından; işgörenlerin örgütsel güven algılarında farklılaşma vardır. Araştırmaya katılan örneklem grubunun cinsiyet değişkenine göre örgütsel güven algısı ve performans düzeylerinde bir farklılaşma olup olmadığı araştırılmış, örgütsel güven ile cinsiyet arasında anlamlı bir farklılaşma tespit edilememiştir $(\mathrm{p}<.05)$. $\mathrm{H}_{4-\text { a. }}$ hipotezi yeterli kanıtla desteklenememiştir.

Topaloğlu (2010) çalışmasında, işgörenlerin örgütsel güven algısının cinsiyete göre değişip değişmediğini test etmek için yapılan $\mathrm{t}$ testinde $(\mathrm{t}=-, 079, \mathrm{p}<.05)$ anlamlı bir farklılaşma görülmemiştir. Hatta erkek işgörenler ( $\bar{X}=3,3792)$ ile kadın işgörenler $\bar{X}=3,3862)$ ortalama ile büyük bir algılama benzerliği göstermişlerdir.

Büte (2011) çalışmasında, örgütsel güvenin alt boyutlarıyla ilgili bir analiz yapmıştır. Alt boyutlarında birtakım farklılıklar görülmüştür. Örgütsel güvenin yöneticiye güven boyutu ile cinsiyet arasında \%5 anlamlllık düzeyinde olumsuz yönde, eğitim durumu arasında \%5 anlamlılık düzeyinde olumlu yönde ilişkiler olduğu saptanmıştır. Örgütsel güvenin çalışma arkadaşlarına güven boyutu ise yaş ve eğitim durumu değişkenleri ile $\% 1$ anlamlılık düzeyinde olumlu yönde; statü değişkeni ile \% 1 anlamlılık düzeyinde olumsuz yönde ilişkilere sahip olduğu saptanmıştır.

$\mathrm{H}_{4 . b}$ : Cinsiyet değişkeni açısından; işgörenlerin örgütsel adalet algılarında farklılaşma vardır. Araştırmaya katılan örneklem grubunun cinsiyet değişkenine göre örgütsel adalet algısında bir farklılaşma olup olmadığı araştırılmış, istatistiksel olarak cinsiyet değişkeni ile örgütsel adalet algısı arasında anlamlı bir farklılaşma tespit edilememiştir ( $\mathrm{p}>.05)$. H4.b. hipotezi yeterli kanıtla desteklenememiştir.

Ay (2014)'ün araştırmasında, değişkenlere verilen yanıtların cinsiyete göre farklılık gösterip göstermediğini belirmek amacı ile t-testi yapılmıştır ancak işgörenlerin adalet algılarının hiçbir boyutunun cinsiyete göre farklılık göstermediği tespit edilmiştir. 
H4.c: Cinsiyet değişkeni açısından; işgörenlerin performans düzeylerinde farklılaşma vardır. Araştırmaya katılan örneklem grubunun cinsiyet değişkenine göre performans düzeyinde bir farklılaşma olup olmadığı araştırılmış, ancak istatistiksel olarak cinsiyet değişkeni ile etkileşimsel adalet algısı arasında anlamlı bir farklılaşma tespit edilememiştir ( $\mathrm{p}>$.05). $\mathrm{H}_{4 . c .}$ hipotezi yeterli kanıtla desteklenememiştir.

Aktaş (2010) çalışmasında, işgörenlerin performans değerlendirme sistemlerine ve örgütsel adalet algılarına göre farklılık analizi bulguları yapmıştır. Değişkenlere verilen yanıtların yaş değişkenine göre farklılık gösterip göstermediğini belirlemek amacı ile yapılan Anova testi sonuçlarına göre anlamlı bir farklılık bulunamamıştır ( $p>0,05)$.

Tablo 14. Çalışma Süresi Değişkeni Açısından; İşgörenlerin Örgütsel Adalet ve Örgütsel Güven Algıları ve Performans Düzeylerindeki Farklılaşma

\begin{tabular}{|c|c|c|c|c|c|c|}
\hline & Çalışma Yılı & $\mathbf{N}$ & $\bar{X}$ & s.s. & $\mathbf{F}$ & p \\
\hline \multirow[t]{6}{*}{ Örgütsel Güven } & $0-1$ & 33 & 3,7205 & 76321 & \multirow[t]{6}{*}{1,667} & \multirow[t]{6}{*}{157} \\
\hline & $2-5$ & 94 & 3,5674 & ,86913 & & \\
\hline & $6-10$ & 77 & 3,5435 & ,78630 & & \\
\hline & $11-15$ & 56 & 3,3492 & ,93305 & & \\
\hline & 16 ve üzeri & 155 & 3,6605 & 83974 & & \\
\hline & Toplam & 415 & 3,5805 & 84715 & & \\
\hline \multirow[t]{6}{*}{ Örgütsel Adalet } & $0-1$ & 33 & 3,5955 & ,72082 & \multirow[t]{6}{*}{1,658} & \multirow[t]{6}{*}{ 159 } \\
\hline & $2-5$ & 94 & 3,4782 & 89489 & & \\
\hline & 6-10 & 77 & 3,4260 & 87259 & & \\
\hline & $11-15$ & 56 & 3,1696 & 1,07786 & & \\
\hline & 16 ve üzeri & 155 & 3,4913 & 89782 & & \\
\hline & Toplam & 415 & 3,4411 & ,90950 & & \\
\hline \multirow{6}{*}{$\begin{array}{l}\text { Performans } \\
\text { Değerlendirme }\end{array}$} & $0-1$ & 33 & 3,9508 & ,72007 & \multirow[t]{6}{*}{2,518} & \multirow[t]{6}{*}{,041 } \\
\hline & $2-5$ & 94 & 4,2340 & ,57625 & & \\
\hline & $6-10$ & 77 & 4,1477 & 83206 & & \\
\hline & $11-15$ & 56 & 4,0893 & ,72681 & & \\
\hline & 16 ve üzeri & 155 & 4,2984 & ,60494 & & \\
\hline & Toplam & 415 & 4,2000 & ,67755 & & \\
\hline
\end{tabular}

H5.a: Çalışma Süresi açısından; işgörenlerin örgütsel güven algılarında farklılık vardır. Çalışma yılı göz önünde bulundurularak yapılan Anova testinde örneklem grubundaki katılımcıların örgütsel güven algılarında kıdem yılı değişkeni açısından $\mathrm{p}<.05$ anlamlılık seviyesinde bir farklılaşma tespit edilememiştir $(\mathrm{p}=, 157)$. Çalışma yılına paralel bir konu olduğundan yaş değişkeni açısından da aynı analizler tekrarlanmış; ancak çalışma yılı değişkeninde olduğu gibi anlamlı bir ilişki tespit edilememiştir. H5.a. hipotezi yeterli kanıtla desteklenememiştir.

Önder (2015) araştırması kapsamına alınan personelin hizmet süreleri açısından birçok araştırmanın aksine arasındaki anlamlı farklılık incelenmiştir. Buna göre; "Yöneticiye Güven" $\mathrm{F}=4,72$, $\mathrm{p}<, 05$ ve "Örgütün Kendine Güven" alt boyutuna ait personel algıları arasında $\mathrm{F}=6,67$, $\mathrm{p}<, 05$ 'e göre anlamlı bir farklılık olduğu görülmektedir. Ancak bu anlamlı farklılık 0-4 yıl grubunun katılımının yüksek olmasından kaynaklanmakta olduğu görülmüştür. 
H5.b. Çalışma süresi açısından; işgörenlerin örgütsel adalet algılarında farlılık vardır. Araştırmaya katılan katılımcıların örgütsel adalet algılarında çalışma süresi değişkeni açısından anlamlı bir farklılaşma bulunamamıştır ( $p>0.05$ ). Tabloya bakıldığında kıdem yıl değişkenleri arasında neredeyse hiç farklılık bulunmamaktadır, birbirine çok yakın değerler elde edilmiştir. 11-15 yıl

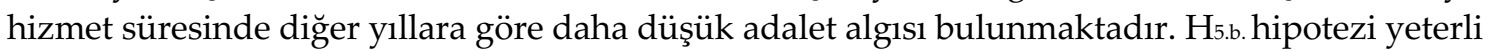
kanıtla desteklenememiştir.

H5.c: Çalışma süresi açısından; işgörenlerin performans düzeyleri arasında farlılık vardır. Araştırmaya katılan katılımcıların performans düzeyleri açısından çalışma süresi değişkeni açısından anlamlı bir farklılaşma bulunmuştur ancak oran 0,041 olmakta ve büyük bir farklılık değildir. ( $p>0.05$ ). 16 yıl ve üzeri hizmet yılına sahip işgörenler kendi performanslarını daha yüksek bulurken ilk 1 hizmet yılındaki işgören performansını daha düşük görmektedir. Ancak denildiği gibi çok büyük bir farklılık bulunmamaktadır. H5.c. hipotezi yeterli kanıtla desteklenmiştir.

Yavuz (2011)'un Ankara'da 1500 çalışan üzerinde yaptığı araştırmada kamu ve özel sektöre göre örgütsel adalet algılarında bir farklılaşmanın olup olmadığını 0.05 önem seviyesinde incelenmiş ve sektörel açıdan istatistiksel olarak bir farklılaşmanın ( $\mathrm{p}=.000)$ anlamlılık seviyesinde olduğu sonucuna ulaşmıştır. Bu araştırmaya göre, kamu kurum ve kuruluşlarında çalışan işgörenlerin örgütsel adalet algıları $(X=2,8765)$ gibi düşük bir ortalamaya sahip iken, özel sektörde çalışan işgörenlerin örgütsel adalet algıları $(X=3,900)$ ortalama ile kamu kurum ve kuruluşlarına göre yüksek olduğu tespit edilmiştir.

Tablo 15. Kamu Ve Özel Kurumlar Açısından; İşgörenlerin Örgütsel Adalet ve Güven Algıları ve Performans Düzeylerindeki Farklılaşma

\begin{tabular}{|l|l|l|l|l|l|l|}
\hline & $\begin{array}{l}\text { Kurum } \\
\text { Türü }\end{array}$ & $\mathbf{N}$ & $\bar{X}$ & s.s. & $\mathbf{T}$ & P \\
\hline \multirow{2}{*}{ Örgütsel Güven } & Kamu & 245 & 3,4574 &, 75767 & $-3,602$ & \multirow{2}{*}{, 000} \\
\cline { 2 - 5 } & Özel & 170 & 3,7577 &, 93578 & & \\
\hline \multirow{2}{*}{ Örgütsel Adalet } & Kamu & 245 & 3,3469 &, 83154 & $-2,548$ & \multirow{2}{*}{011} \\
\cline { 2 - 5 } & Özel & 170 & 3,5768 &, 99834 & & \\
\hline \multirow{2}{*}{ Performans } & Kamu & 245 & 4,1235 &, 67262 & $-2,785$ & \multirow{2}{*}{006} \\
\cline { 2 - 5 } & Özel & 170 & 4,3103 &, 67132 & & \\
\hline
\end{tabular}

$\mathrm{H}_{6 . a}:$ Kamu ve özel kurumlar açısından; işgörenlerin örgütsel güven algılarında farlılık vardır. Araştırmaya katılan örneklem grubunun kurum türü değişkeni açısından örgütsel güven algılarında bir farklılaşma olup olmadığına bakılmış olup 0,05 anlamlılık düzeyinde anlamlı farklılaşmalar tespit edilmiştir. Örgütsel adalet algısı incelendiğinde $X=3,75$ ile özel kurumlarda çalışan işgörenlerin kamu kurumlarında çalışan işgörenlere göre $(X=3,45)$ adalet algılarının daha yüksek olduğu dikkat çekmektedir. Diğer bir ifade ile 61.a. hipotezi yeterli kanıtla desteklenmiştir.

H6.b: Kamu ve özel kurumlar açısından; işgörenlerin örgütsel adalet algılarında farlılık vardır. Araştırmaya katılan örneklem grubunun kurum türü değişkeni açısından örgütsel adalet algılarında bir farklılaşma olup olmadığına bakılmış olup p $<0,05$ anlamlılık düzeyinde anlamlı farklılaşmalar tespit edilmiştir. Örgütsel adalet algısı incelendiğinde $X=3,57$ ile özel kurumlarda çalışan işgörenlerin kamu kurumlarında çalışan işgörenlere göre $(X=3,34)$ adalet algılarının daha yüksek olduğu tespit edilmiştir. Diğer bir ifade ile H6.b. hipotezi yeterli kanıtla desteklenmiştir. 
$\mathrm{H}_{6 . c:}$ Kamu ve kurumlar açısından; işgörenlerin performans düzeylerinde farlılık vardır. Araştırmaya katılan örneklem grubunun kurum türü değişkeni açısından performans düzeylerinde bir farklılaşma olup olmadığına bakılmış olup 0,05 anlamlılık düzeyinde anlamlı farklılaşmalar tespit edilmiştir. Performans düzeyleri incelendiğinde $X=4,31$ ile özel kurumlarda çalışan işgörenlerin kamu kurumlarında çalışan işgörenlere göre performans ortalamalarının ( $X$ $=4,12$ ) daha yüksek olduğu dikkat çekmektedir. H6.c. hipotezi yeterli kanıtla desteklenmiştir.

Tablo 16. Yaş Değişkeni Açısından; İşgörenlerin Örgütsel Adalet ve Güven Algıları ve Performans Düzeylerindeki Farklılaşma

\begin{tabular}{|c|c|c|c|c|c|c|}
\hline & Yaş & $\mathbf{N}$ & $\bar{X}$ & s.s. & F & $\mathbf{P}$ \\
\hline \multirow{6}{*}{ Örgütsel Güven } & $20-25$ & 46 & 3,6795 & ,86920 & \multirow{6}{*}{1,127} & \multirow{6}{*}{, 343} \\
\hline & $26-30$ & 68 & 3,5632 & ,79104 & & \\
\hline & $31-35$ & 87 & 3,4321 & 82821 & & \\
\hline & $36-40$ & 68 & 3,5599 & ,90173 & & \\
\hline & 41 üzeri & 146 & 3,6553 & 84888 & & \\
\hline & Toplam & 415 & 3,5805 & ,84715 & & \\
\hline \multirow{6}{*}{ Örgütsel Adalet } & $20-25$ & 46 & 3,5380 & ,89698 & \multirow{6}{*}{,941 } & \multirow{6}{*}{440} \\
\hline & $26-30$ & 68 & 3,5243 & 85004 & & \\
\hline & $31-35$ & 87 & 3,3098 & ,89867 & & \\
\hline & $36-40$ & 68 & 3,3632 & 96987 & & \\
\hline & 41 üzeri & 146 & 3,4863 & ,91820 & & \\
\hline & Toplam & 415 & 3,4411 & ,90950 & & \\
\hline \multirow{6}{*}{$\begin{array}{l}\text { Performans } \\
\text { Değerlendirme }\end{array}$} & $20-25$ & 46 & 4,0190 & 64655 & \multirow{6}{*}{1,206} & \multirow{6}{*}{ 308 } \\
\hline & $26-30$ & 68 & 4,2390 & 67565 & & \\
\hline & $31-35$ & 87 & 4,1739 & ,73812 & & \\
\hline & $36-40$ & 68 & 4,1875 & ,73286 & & \\
\hline & 41 üzeri & 146 & 4,2603 & 61929 & & \\
\hline & Toplam & 415 & 4,2000 & 67755 & & \\
\hline
\end{tabular}

H7.a: Yaş değişkeni açısından; işgörenlerin örgütsel güven algılarında farklılık vardır. İşgörenlerin örgütsel güven algılarında yaş değişkenine göre farklılaşma durumunu ölçmek amacıyla yapılan one-way anova testi yapılmıştır. Analiz sonuçlarına göre güven algı düzeylerinde anlamlı bir farklılaşma görülmemiştir. ( $p=, 343)$ Yaşın herhangi bir etkisi yoktur. H7a. hipotezi yeterli kanıtla desteklenememiştir.

Taşkın ve Dilek (2010) bir alan araştırması sonucunda aksine bir durum saptamıştır. İşgörenlerin örgütsel güvenle ilişkili görüşlerinin yaş gruplarına göre farklılık görülmüştür. Değişikliğin görüldüğü yaş grubu ise 46 yaş ve üzeri grubudur. Bizim çalışmamızda ise yaş bazında herhangi bir etki görülmemiştir.

H7.b: Yaş değişkeni açısından; işgörenlerin örgütsel adalet algılarında farlılık vardır. Araştırmaya katılan işgörenlerin örgütsel adalet algısı, yaşlara göre karşılaştırması yapılan Anova testi sonucunda anlamlı bir farklılık görülmemiştir. H7.b. hipotezi yeterli kanıtla desteklenememiştir.

İşcan ve Sayın (2010) araştırmasında da çalışmamıza paralel olarak yaş değişkeni açısından örgütsel adalet bazında anlamlı bir farklılık saptamamıştır. 
H7.c: Yaş değişkeni açısından; işgörenlerin performans düzeylerinde farlılık vardır. Araştırmaya katılan işgörenlerin performans düzeyi, yaşa göre karşılaştırması yapılan anova testi sonucunda anlamlı bir farklılık görülmemiştir. $\mathrm{H}_{7 . c .}$ hipotezi yeterli kanıtla desteklenememiştir.

Tablo 17. Eğitim Durumu Değişkeni Açısından; İşgörenlerin Örgütsel Adalet ve Güven Algıları ve Performans Düzeylerindeki Farklılaşma

\begin{tabular}{|c|c|c|c|c|c|c|}
\hline & Eğitim Durumu & $\mathbf{N}$ & $\bar{X}$ & s.s. & $\mathbf{F}$ & $\mathbf{P}$ \\
\hline \multirow{6}{*}{ Örgütsel Güven } & İlköğretim & 27 & 3,8711 & 66678 & \multirow{6}{*}{2,726} & \multirow{6}{*}{,029 } \\
\hline & Lise & 98 & 3,3930 & ,81510 & & \\
\hline & Önlisans & 57 & 3,6420 & 78929 & & \\
\hline & Lisans & 178 & 3,6558 & ,87025 & & \\
\hline & Yüksek Lisans & 55 & 3,4640 & ,90752 & & \\
\hline & Toplam & 415 & 3,5805 & 84715 & & \\
\hline \multirow{6}{*}{ Örgütsel Adalet } & İlköğretim & 27 & 3,5037 & ,89162 & \multirow{6}{*}{1,085} & \multirow{6}{*}{,363 } \\
\hline & Lise & 98 & 3,3878 & 84148 & & \\
\hline & Önlisans & 57 & 3,5649 & ,89113 & & \\
\hline & Lisans & 178 & 3,4809 & ,93393 & & \\
\hline & Yüksek Lisans & 55 & 3,2482 & ,96858 & & \\
\hline & Toplam & 415 & 3,4411 & ,90950 & & \\
\hline \multirow{6}{*}{ Performans } & İlköğretim & 27 & 4,3148 & 61469 & \multirow{6}{*}{468} & \multirow{6}{*}{,760 } \\
\hline & Lise & 98 & 4,1454 & 71587 & & \\
\hline & Önlisans & 57 & 4,2588 & 62761 & & \\
\hline & Lisans & 178 & 4,1994 & ,70026 & & \\
\hline & Yüksek Lisans & 55 & 4,1818 & 62073 & & \\
\hline & Toplam & 415 & 4,2000 & ,67755 & & \\
\hline
\end{tabular}

H8.a: Eğitim durumu değişkeni açısından; işgörenlerin örgütsel güven algılarında farklılık vardır. İşgörenlerin örgütsel güven algılarında eğitim durumu değişkenine göre farklılaşma durumunu ölçmek amacıyla yapılan one-way anova testi yapılmıştır. Analiz sonuçlarına göre güven algı düzeylerinde anlamlı bir farklılaşma görülmüştür. $(p=, 029)$. Lise mezunu işgörenlerin $(X=3,39)$ ve lisansüstü mezunu işgörenlerin $(X=3,46)$ örgütlerinde güven algıları diğer işgörenlere göre daha azdır. Anlamlı bir farklılaşma görülmektedir. En yüksek güven algısı ise ilkokul mezunu

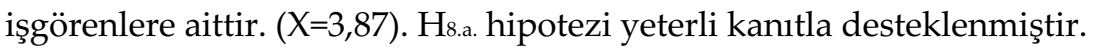

İşcan ve Sayın (2010) araştırmasında da çalışmamıza paralel olarak eğitim değişkeni açısından örgütsel güven bazında anlamlı bir farklılık saptanmış araştırmanın söz konusu teorisi desteklenmiştir. Bunun nedeni ayrıca araştırıldığında ise öğrenim seviyesi arttıkça olumlu puanlamaların arttığı tespit edilmiştir.

İşgören açısından örgütsel bağl1lığın örgütsel güven ile ilişkili bir kavram olduğunu düşünürsek Taşkın ve Dilek (2010) gerçekleştirmiş olduğu bir alan araştırmasında, yüksek lisans ve doktora yapmış işgörenlerin anketlere vermiş olduğu ortalama puanlar diğer işgörenlere nazaran yüksek tespit edilmiştir. İşgörenlerin görüşleri açısından anlamlı bir farklılık olduğu görülmüştür.

H8.b: Eğitim durumu değişkeni açısından; işgörenlerin örgütsel adalet algılarında farlılık vardır. Araştırmaya katılan işgörenlerin örgütsel adalet algısı, eğitim durumlarına göre karşılaştırması yapılan anova testi sonucunda anlamlı bir farklılık görülmemiştir $(p=, 363) \mathrm{H}$ 8.b. hipotezi yeterli 
kanıtla desteklenememiştir. İşcan ve Sayın (2010) araştırmasında da çalışmamıza paralel olarak eğitim değişkeni açısından örgütsel adalet bazında anlamlı bir farklılık saptamamıştır.

H8.c: Eğitim durumu değişkeni açısından; işgörenlerin performans düzeylerinde farlılık vardır. Araştırmaya katılan işgörenlerin performans düzeyi, eğitim durumuna göre karşılaştırması

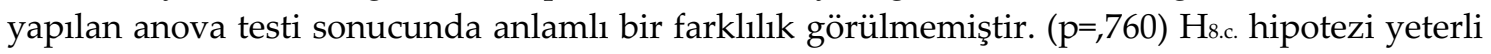
kanitla desteklenememişti

Tablo 18. Yöneticilik Durumu Değişkeni Açısından; İşgörenlerin Örgütsel Adalet ve Güven Algıları ve Performans Düzeylerindeki Farklılaşma

\begin{tabular}{|l|l|l|l|l|l|l|}
\hline & Yöneticilik Durumu & $\mathbf{N}$ & $\bar{X}$ & s.s. & $\mathbf{t}$ & P \\
\hline \multirow{2}{*}{ Örgütsel Güven } & Evet & 94 & 3,7132 &, 92557 & \multirow{2}{*}{1,731} & \multirow{2}{*}{, 084} \\
\cline { 2 - 5 } & Hayır & 321 & 3,5416 &, 82025 & & \\
\hline \multirow{2}{*}{ Örgütsel Adalet } & Evet & 94 & 3,5862 &, 97714 & \multirow{2}{*}{, 763} & \multirow{2}{*}{, 079} \\
\cline { 2 - 5 } & Hayır & 321 & 3,3986 &, 88583 & & \multirow{2}{*}{, 404} \\
\hline Performans & Evet & 94 & 4,2513 &, 66813 & \multirow{2}{*}{, 635} \\
\cline { 2 - 5 } & Hayır & 321 & 4,1850 &, 68058 & & \\
\end{tabular}

H9.a: Yöneticilik durumu açısından; işgörenlerin örgütsel güven algılarında farlılık vardır. Araştırmaya katılan örneklem grubunun yöneticilik değişkeni açısından örgütsel güven algılarında bir farklılaşma olup olmadığına bakılmış olup 0,05 anlamlılık düzeyinde anlamlı farklılaşmalar tespit edilememiştir. Ancak ortalamalara bakıldığında yönetici işgörenlerin güven algıları daha yüksektir. Diğer bir ifade ile H9.a. hipotezi yeterli kanıtla desteklenmemiştir.

H9.b: Yöneticilik durumu açısından; işgörenlerin örgütsel adalet algılarında farklılık vardır. Yöneticiliğin olup olmaması değişkeni göz önünde bulundurularak yapılan Anova testinde örneklem grubundaki katılımcıların örgütsel adalet algılarında yöneticilik değişkeni açısından $\mathrm{p}<.05$ anlamlılık seviyesinde bir farklılaşma tespit edilememiştir. Ancak burada da anlamlı bir ilişki tespit edilememiştir. H9.b. hipotezi yeterli kanıtla desteklenememiştir.

H9.c: Yöneticilik durumu açısından; işgörenlerin performans düzeylerinde farlılık vardır. Araştırmaya katılan örneklem grubunun yöneticilik değişkeni açısından performansalarında bir farklılaşma olup olmadığına bakılmış olup 0,05 anlamlılık düzeyinde anlamlı farklılaşmalar tespit edilememiştir. Ancak ortalamalara bakıldığında yönetici işgörenlerin güven algıları daha yüksektir. Diğer bir ifade ile H9.c. hipotezi yeterli kanıtla desteklenmemiştir.

\section{SONUÇ VE ÖNERILLER}

Araştırmada sonucunda elde edilen sonuçlara bakıldığında araştırmanın problemini destekleyici sonuçlar ortaya çıkmıştır. Araştırmada yapılan analiz ve testler incelendiğinde sonuçlar aşağıdaki gibidir:

1- Araştırmaya katılan işgörenlerin örgütsel güven ve örgütsel adalet algıları ölçülmüştür. İşgörenlerin örgütsel güven algıları örgütsel adalet algılarından daha yüksektir. Bunun yanı sıra kendi performanslarını değerlendirmeleri de istenmiştir ve sonucu adalet ve güven algılarına göre daha yüksek çıkmıştır. Buradan örgütsel güvenin yükseltilmesi ile performansın iyileştirilmesi mümkün olabileceği sonucuna ulaşılabilir. 
2- $\quad$ İşgörenlerin örgütsel adalet algılarıyla örgütsel güven algıları arasındaki ilişkinin anlamlılı̆̆ının oldukça yüksek olduğu tespit edilmiştir. H1. Hipotezi desteklenmiştir. Örgütsel adalet algısı ile örgütsel güven arasında ilişkinin olduğu söylenebilir.

3- Katılımcı işgörenlerin örgütsel güven algılarıyla performans düzeyleri arasındaki anlamlılığın da yüksek olduğu tespit edilmiş olup $\mathrm{H}_{2}$. Hipotezi desteklenmiştir. Örgütsel güven algısını mümkün olduğunca örgütte yükselterek performans düzeyini yükseltmek mümkündür. 4- $\quad$ Araştırma grubunun örgütsel adalet algılarıyla performans düzeyleri arasındaki ilişkinin anlamlılığının oldukça yüksek olduğu tespit edilmiştir. $\mathrm{H}_{3}$. Hipotezi desteklenmiştir. Örgütsel adalet algısının artması performansın da artacağının göstergesidir denilebilir.

5- $\quad$ Araştırma grubunun örgütsel güven ve adalet algılarının, performans düzeylerine etkisine ilişkin "çoklu regresyon analizi" yapılmıştır. Model istatistiksel olarak anlamlı bulunmuştur. İşgörenin örgütsel güven algısının performans üzerine $\% 14,1$ oranında, adalet algısının ise \%12,1 oranında etkisi bulunmaktadır. Neticede performans bağlamında işgören algisında güvenin önem daha büyüktür.

6- $\quad$ Araştırma grubunun cinsiyet değişkenine göre örgütsel algısında istatistiksel olarak anlamlı bir farklılaşma tespit edilememiştir. $\mathrm{H}$ 1.a. Hipotezi yeterli kanıtla desteklenememiştir. Topaloğlu (2010) çalışmasında, işgörenin örgütsel güven algısının cinsiyete göre değişiklik gösterip göstermediğini test etmek için $\mathrm{t}$ testi yapmış ve herhangi bir farklılaşma görülmemiştir. Hatta rakamlarda hemen hemen birebir benzeşme görülmüştür.

7- $\quad$ Araştırma grubunun cinsiyet değişkenine göre örgütsel adalet algısında istatistiksel olarak anlamlı bir farklılaşma tespit edilememiştir. $\mathrm{H}_{2 . a}$. Hipotezi yeterli kanıtla desteklenememiştir. Ay (2014)'ın araştırmasında da bizim çalışmamızın paralelinde bir sonuç elde edilmiştir. Adaletin hiçbir alt boyutunda anlamlı farklılaşma elde edilmemiştir. Adalet algısında kadın erkek farklılığı görülmemektedir.

8- $\quad$ Araştırma grubunun cinsiyet değişkenine göre performans düzeyinde istatistiksel olarak anlamlı bir farklılaşma tespit edilememiştir. $\mathrm{H}$ 3.a. Hipotezi yeterli kanıtla desteklenememiştir. Aktaş (2010) araştırmasında, işgörenlerin değerlendirme sistemlerine ve örgütsel adalet algılarına göre farklılık analizi bulguları yapmıştır. Değişkenlere verilen yanıtların yaş değişkenlerine göre farklılık gösterip göstermediğini belirlemevek amacı ile yapılan Anova testi sonuçlarına göre anlamlı bir farklılık bulunamamıştır ( $\mathrm{p}<.05)$.

9- $\quad$ Araştırma grubunun örgütsel güven algılarında çalışma yılı değişkeni açısından anlamlı bir farklılık tespit edilememiştir. H1.b. Hipotezi desteklenememiştir.

10- Araştırmaya katılan katılımcıların örgütsel adalet algılarında çalışma süresi değişkeni açısından anlamlı bir farklılaşma bulunamamıştır. $H_{2 . b .}$ Hipotezi yeterli kanıtla desteklenememiştir. Çalışma süresi 11-15 yıl olan işgörenlerin örgütsel adalet algılarının daha düşük olduğu görülmüştür. Diğer kıdem yılı değişkenleri arasında birbirine çok yakın değerler elde edilmiştir, hemen hemen hiç değişiklik bulunmamaktadır.

11- $\quad$ Araştırma grubunun performans düzeyleri çalışma yılı değişkeni açısından anlamlı bir farklılaşma tespit edilmiştir. H3.b. Hipotezi yeterli kanıtla desteklenmiştir. 16 yıl ve üzeri hizmet yılına sahip işgörenler kendi performanslarını daha yüksek bulurken ilk 1 hizmet yılındaki işgören performansını daha düşük görmektedir. Ancak çok büyük bir farklılık bulunmamaktadır.

12- Araştırmaya katılan örneklem grubunun kurum türü değişkeni açısından örgütsel güven algılarında anlamlı bir farklılaşma bulunmuştur. Özel kurumlarda çalışan işgörenlerin kamu kurumlarında çalışan işgörenlere göre güven algılarının daha yüksek olduğu dikkat çekmektedir. H1.c. Hipotezi yeterli kanıtla desteklenmiştir.

13- Araştırma grubunun kurum türü değişkeni açısından örgütsel adalet algısında 0,05 anlamlılık düzeyinde farklılaşma tespit edilmiştir. Analiz sonucuna göre; özel kurumlarda çalışan işgörenlerin kamu kurumlarında çalışan işgörenlere göre adalet algılarının daha yüksek 
olduğu dikkat çekmektedir. Diğer bir ifade ile $\mathrm{H}_{2}$.c. Hipotezi yeterli kanıtla desteklenmiştir. Literatürde işletme çalışanları için yapılan araştırmalarda da özel işletme çalışanlarının örgütsel adalet algılarının kamuda çalışanlara göre daha yüksek olduğu görülmüştür. Yapılan analiz sonuçları, literatürdeki çalışmaları destekler niteliktedir.

14- Araştırma grubunun kurum türü değişkeni açısından performans düzeylerinde farklılaşma tespit edilmiştir. Analiz sonucuna göre; özel kurumlarda çalışan işgörenlerin kamu kurumlarında çalışan işgörenlere göre performans düzeylerinde yüksek olduğu dikkat çekmektedir. H3.c. Hipotezi yeterli kanıtla desteklenmiştir. Özel kurumlarda çalışan işgörenlerin performansının kamu kurumlarında görev yapanlara göre daha yüksek olduğu anlamlılık seviyesindedir.

15- Çalışma yılına paralel bir konu olduğundan yaş değişkeni açısından da aynı analizler tekrarlanmış; ancak çalışma yılı değişkeninde olduğu gibi anlamlı bir farklılaşma tespit edilememiştir. İşgörenlerin örgütsel güven algısında, yaş değişkeni açısından anlamlı bir farklılaşma tespit edilememiştir. H1.d. Hipotezi yeterli kanitla desteklenememiştir.

16- İşgörenlerin örgütsel adalet algısında, yaş değişkeni açısından anlamlı bir farklılaşma

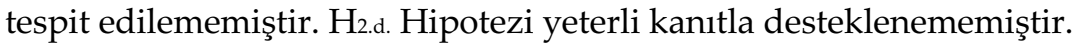

17- Araştırmaya katılan işgörenlerin performans düzeylerinde yaş değişkeni açısından $p>.05$

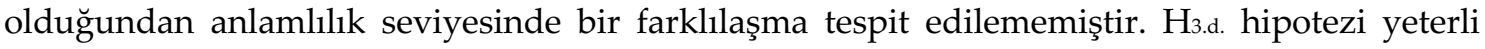
kanitla desteklenememiştir.

18- İşgörenlerin eğitim durumu değişkeni açısından, örgütsel güven algılarında önemli bir farklılık bulunmuştur. İşgörenlerin örgütsel güven algılarında eğitim durumu değişkenine göre farklılaşma durumunu ölçmek amacıyla yapılan one-way Anova testi yapılmıştır. Analiz sonuçlarına göre güven algı düzeylerinde anlamlı bir farklılaşma görülmüştür. $(p=, 029)$. Lise mezunu işgörenlerin ve lisansüstü mezunu işgörenlerin örgütlerinde güven algıları diğer işgörenlere göre daha azdır. Anlamlı bir farklılaşma görülmektedir. En yüksek güven algısı ise ilkokul mezunu işgörenlere aittir. H1.e. hipotezi yeterli kanıtla desteklenmiştir.

19- İşgörenlerin örgütsel adalet algısında, eğitim durumu değişkeni açısından anlamlı bir farklılaşma tespit edilememiştir. $\mathrm{H}_{2 . e .}$. Hipotezi yeterli kanıtla desteklenememiştir.

20- Araştırmaya katılan işgörenlerin performans düzeylerinde eğitim durumu değişkeni açısından $p>.05$ olduğundan anlamlılık seviyesinde bir farklılaşma tespit edilememiştir. $\mathrm{H}_{3 . e .}$ hipotezi yeterli kanttla desteklenememiştir.

21- Yöneticilik durumu değiş̧keni açısından da aynı analizler tekrarlanmış; ancak çalışma yılı ve yaş değişkeninde olduğu gibi anlamlı bir farklılaşma tespit edilememiştir.

Araştırmanın bu bölümünde, araştırma bulgularına dayalı olarak uygulayıcılar ve konu ile ilgili çalışma yapacak araştırmacılara yönelik için şu önerilerde bulunulabilir:

1- $\quad$ Araştırmada zaman kısıtlılığı nedeniyle bölgesel farklılık değişkeni açısından örgütsel adalet ve güven algısı ile performans arasındaki ilişki araştırılamamıştır. Bölgesel farklılıklar değişkeni dikkate alınarak araştırma yapılabilir.

2- İleride yapılacak olan araştırmalarda işgörenlerle yüz yüze görüşerek sonuçlar analiz edilebilir.

3- Özel kurumlardaki işgörenlerin güven algısının kamu kurumlarındaki işgörenlerden daha yüksek olduğu tespit edilmiştir. Kamu kurumlarındaki güven algısını etkileyen faktörler tespit edilmeli, algının artırılması için çalışmalar yapılmalı ve böylece işgörenlerin performans seviyeleri yükseltilmelidir.

4- $\quad$ Özel kurumlardaki işgörenlerin adalet algısının kamu kurumlarındaki işgörenlerden daha yüksek olduğu tespit edilmiştir. Kamu kurumlarındaki adalet algısını etkileyen faktörler 
tespit edilmeli, algının artırılması için çalışmalar yapılmalı ve böylece işgörenlerin performans seviyeleri yükseltilmesi mümkündür.

5- $\quad$ Araştırma grubundaki işgörenlerin adalet algılarının alt boyutları açısından incelenebilir.

6- Kamu kurumunda çalışan işgörenler ile özel kurumda çalışan işgörenlerin adalet ve güven algılarındaki özellikler birbirinden farklıdır. Her iki gruptaki çalışanlar için adaleti ve güveni etkileyen faktörler analiz edilebilir ve her iki grup için de farklı ölçekler geliştirilebilir.

7- Çalışma imkân dâhilinde yalnızca başkentimiz Ankara ili ile sınırlı kalmıştır. Araştırma farklı illerdeki işgörenler dâhil edilerek derinleştirilebilir.

8- $\quad$ Araştırmaya katılan işgörenlere uyguladığımız performans değerlendirme ölçeği kişinin kendisinin performansını gene kendisinin değerlendirdiği bir ölçektir. Daha doğru sonuçların elde edilebilmesi için performans değerlendirmesinin farklı ölçeklerle ölçülüp doğruya en doğru sonuçların alınması mümkündür. Burada önemli olan en doğru ve en adil performans değerlendirmesinin yapılacak olmasıdır.

\section{KAYNAKÇA}

Aktaş, E. (2010). Performans Değerlendirme Sistemlerinin Örgütsel Adalet Algısı Üzerine Etkisi, Yüksek Lisans Tezi,_Dokuz Eylül Üniversitesi, İzmir.

Ankara Kalkınma Ajansı, (2017). İstatistiklerle Ankara 2017, Ankara. (www.ankara.org.tr)

Ay, G. (2013). Öğretmenlerin Örgütsel Adalet Algıları İle Örgütsel Bağlllık Düzeyleri Arasındaki İlişkinin Belirlenmesine Yönelik Karşılaştırmalı Bir Araştırma, Yüksek Lisans Tezi, Gazi Üniversitesi Eğitim Bilimleri Enstitüsü, Ankara.

Büte, M. (2011). Etik İklim, Örgütsel Güven ve Bireysel Performans Arasındaki İlişki, Atatürk Üniversitesi İktisadi İdari Bilimler Dergisi, 25(1):171-192.

Cihangiroğlu, N. ve Yılmaz, A. (2010). İşgörenların Örgütsel Adalet Algısının Örgütler için Önemi, SÜ İ̈BF Sosyal ve Ekonomik Araştırmalar Dergisi, 13(9):195-213.

Cohen, Allan R. (1992). Effective Behavior in Organisations, Irwin Inc. USA, s. 192.

Ekiyor, A. ve Karagül, S. (2016). Sağlık Sektöründe Personel Güçlendirmenin İşgören Performansına ve İç Girişimciliğe Etkisi, 1(3):13-25.

İşcan, Ö. F. ve Sayın, U. (2010). Örgütsel Adalet, İş Tatmini ve Örgütsel Güven Arasındaki İlişki, Atatürk Üniversitesi İktisadi ve İdari Bilimler Dergisi, 24(4):195-216.

Moorman, R. (1991). Relationship Between Organizational Justice and Organizational Citizenship Behaviors: Do Fairness Perceptions İnfluence Employee Citizenship? The Journal of Applied Psychol, 76:845-855.

Özdamar, K., (2002). Paket Programlar İle İstatistiksel Veri Analizi. Eskişehir: Kaan Kitap Evi, s.673.

Önder, M. (2015). Devlet ve Vakıf Üniversitelerinde Çalışan Personelin Örgütsel Güven Algıları (Ankara İli Örneği), Gazi Üniversitesi, Yüksek Lisans Tezi, Ankara. 
Taşkın, F. ve Dilek, R. (2010). Örgütsel Güven ve Örgütsel Bağlılık Üzerine Bir Alan Araştırması, Organizasyon ve Yönetim Bilimleri Dergisi, 2(1):37-46.

Tezbaşaran, A.A. (2008). Likert Tipi Ölçek Hazırlama Klavuzu. Mersin: 3.Sürüm E-Kitap.

Tokgöz, E., (2012) Örgütsel Güven, Örgütsel Özdeşleşme ve Örgütsel Vatandaşlık Davranış1 Arasındaki İlişki: Bir Devlet Hastanesinde Araştırma, (Basılmamış Yüksek Lisans Tezi, Balıkesir Üniversitesi, Balıkesir).

Tokgöz, E. ve Aytemiz Seymen, O. (2013). Örgütsel Güven, Örgütsel Özdeşleşme ve Örgütsel Vatandaşlık Davranışı Arasındaki İlişki: Bir Devlet Hastanesinde Araştırma, Marmara Üniversitesi Sosyal Bilimler Enstitüsü Hakemli Dergisi, 10(39):61-76.

Topaloğlu, I. G., (2010). İşgörenlerin Adalet ve Etik Algıları Açısından Örgütsel Güven ile Örgütsel Bağlllık İlişkisi, Yüksek Lisans Tezi, Atılım Üniversitesi, Ankara.

Üner, M. (2008). Genel İşletmecilik, Detay Yayıncılık, Ankara.

Yaldız, E. (2007). Kavramsal Düzeyde Etkinlik, Etkililik ve Verimlilik Olgularına Bir Bakış, www.geocities.ws/ceteris tr2/e yaldiz.doc, Ziyaret Tarihi: Aralık 2017.

Yavuz, E. (2011). Kamu ve Özel Sektör Çalışanlarının Örgütsel Adalet Algılamaları Üzerine Bir Karşılaştırma Çalışması. Doğuş Üniversitesi Dergisi, 11(2): 302-312.

Yeniçeri, Ö. ve Demirel, Y. (2011). Yönetimde Birey ve Örgüt Odaklı Davranışlar, Ekin Basım Yayınevi, Bursa. 